\title{
WATER QUALITY AND WASTE CONTAMINATION STUDY IN CATFISH REARING RECIRCULATING AQUACULTURE SYSTEM
}

Gražina ŽIBIENĖ, Hydraulic Engineering Institute, Faculty of Water and Land Management, Aleksandras Stulginskis University. Address: Universiteto 10, Akademija 53361, Kaunas district, Lithuania. E-mail: grazina.zibiene@asu.lt.

Alvydas ŽIBAS, Hydraulic Engineering Institute, Faculty of Water and Land Management, Address: Studentų 11, Akademija 53361, Kaunas district, Lithuania. E-mail: alvydas.zibas@asu.lt.

In this article we analyse catfish rearing conditions in recirculating aquaculture systems (RAS). Based on research, performed by scientists from different countries, we evaluated optimal water parameter values for catfish rearing. African catfish growing process and with it associated factors were researched in JC „Šamas“. The amount of dissolved oxygen (on average 4,53 mg/l) in the rearing basin is adequate for the catfish to feel comfortable and for biomass growth. Water temperature only varies slightly - the average water temperature is $23,3^{\circ} \mathrm{C}$. The ideal $\mathrm{pH}$ for rearing fish in RAS is 7.0. Many aquaculture species continue to feel comfortable in $\mathrm{pH}$ boundaries of 6.5-8.5. In the samples, taken from catfish rearing system, the $\mathrm{pH}$ varied from 5.58 to 6.63 . Such acidic water decreases the effectiveness of biological filter, but also decreases the toxic effect of excreted ammonia on the fish. Only a small amount of suspended solid is present in the samples, which means that they are being removed properly. The average amount of ammonia nitrogen in the water basins in analysed catfish rearing systems is $1,171 \mathrm{mg} / \mathrm{l}$. The analysed water samples presented an average nitrite amount of $0,974 \mathrm{mg} / \mathrm{l}$. The recommended amount of nitrites for catfish is less than $0.5 \mathrm{mg} / \mathrm{l}$. The analysed samples presented relatively high nitrate values - from 412 to $495 \mathrm{mg} / \mathrm{l}$. In order to decrease the concentration of accumulated nitrates it is required to change no less than $10 \%$ of total system water volume every day. The index of consumed biochemical oxygen corresponds to the requirements for water quality in RAS

Keywords: aquaculture, recirculating aquaculture systems, water, wastewater quality

\section{INTRODUCTION}

In order to ensure optimal conditions for fish, grown in recirculating aquaculture systems (RAS), many physical and chemical water parameters need to be controlled: concentration of dissolved oxygen, amounts of ammonia, nitrites, nitrates and carbon dioxide, BOD, alkalinity, $\mathrm{pH}$ and others.

The first factor, limiting the production in every aquaculture system is the amount of oxygen, dissolved in water (oxygen concentration is measured in $\mathrm{mg} / \mathrm{l}$ or percent from saturation value). According to Pillay and Kutty (2005), depending on the species, for optimal fish growth, no less that 5,0 mg/l (for warm water fish) and 7,0 mg/l dissolved oxygen concentration (for cold water fish) is required for optimal fish growth. In aquaculture practice, the main factor determining oxygen solubility in water is temperature. As water temperature rises, oxygen solubility decreases, while the metabolic activity of water organisms, as well as their oxygen requirement increases. Salmonid fish are more sensitive to oxygen deficiency and it is considered that they are able to absorb dissolved oxygen when its relative concentration is not lower than $60 \%$ of its saturation value (Goryczko, 1999). Warm water fish are more immune to oxygen deficiency - the lower boundary for them varies from as low to $30 \%$ to $50 \%$ of saturation value (Ulikowski, 2004). In RAS, the oxygen is consumed not only by the reared organisms; organic pollution and oxygen, consumed for nitrogen oxidation in biofilters also increase oxygen requirements (Parker, 2000). Timmons et al. (2002) state that the proportion of oxygen to consumed feed mass volume is around $0.25: 1$. Other authors present this proportion for fish to be 0.46-0.50:1 (Forsberg, 1997).

The ability to regulate temperature in RAS is a major advantage of this technology. By regulating temperature, it is possible to accelerate the development of various reared fish and avoid the seasonal prevalence of production. Temperature also influences the solubility of oxygen, nitrogen and ammonia in water. Water temperature influences fish metabolism and biochemical processes. Each fish species has their specific water temperature tolerance boundaries. Within these boundaries there is optimal growth and breeding temperature, which can change as the fish grows. By increasing water temperature by $10^{\circ} \mathrm{C}$, the speed of metabolism increases twofold, which is connected to higher consumption of feed and faster growth, but also increased biological oxygen consumption (Badiola et al., 2012). 
Another limiting factor in intensive RAS is the toxic effect of ammonia, accumulated in water. Ammonia is an extremely water-soluble compound. In water it dissociates, turning into ammonium - $\mathrm{NH}_{3} \leftrightarrow \mathrm{NH}_{4}{ }^{+}$.

Ammonia is a secondary product of water animal metabolism. In water, depending on $\mathrm{pH}$ levels, ammonia is found in either ionized $\left(\mathrm{NH}_{4}^{+}\right)$or non-ionized $\left(\mathrm{NH}_{3}\right)$ state. The sum of both compound volumes is the total ammonia nitrogen (TAN). Relative ammonia concentration depends on water $\mathrm{pH}$ levels, salinity and temperature (Pillay and Kutty, 2005). According to Timmons et al. (2002), when consuming $1.0 \mathrm{mg} / \mathrm{l}$ of oxygen per minute, the fish can produce $0.14 \mathrm{mg}$ of TAN, while salmonid fish, under oxygen consumption of $1.0 \mathrm{mg} / \mathrm{l}$, produces $0.04-0.06 \mathrm{mg} / \mathrm{l}$ of TAN (Aquafarmer, 2004). $\mathrm{NH}_{3}-\mathrm{N}$ is the most toxic form of ammonia, thus the toxicity of TAN depends on the percentage of $\mathrm{NH}_{3}$ in TAN concentration. $\mathrm{NH}_{3}-\mathrm{N}$ proportions increase as $\mathrm{pH}$ rises and temperature, as well as salinity, decreases (Timmons et al. 2002). Fivelstad et al. (1995) found that a salinity of certain value decreases the toxicity of ammonia for Atlantic salmon fingerlings. The level of ammonia concentration is not a problem in simple flowing systems, but it becomes a problem in RAS, in which biofilters are used to discard ammonia from the system. Fish can die if the concentration of $\mathrm{NH}_{3}-\mathrm{N}$ is too high.

The intermediate product of ammonia oxidation - nitrites $\left(\mathrm{NO}_{2}\right)$ are harmful for water organisms in relatively low concentrations - higher than $2.0 \mathrm{mg} / \mathrm{l}$ (Sandu, 2000, Meinelt et al., 2010). The deadly concentration for rainbow trout (Oncorhynchus mykiss) after 24 hours is held to be at $1.8 \mathrm{mg} \mathrm{NO}-\mathrm{N} / 1$ (Hagopian and Riley, 1998). The final product of oxidation are nitrates $\left(\mathrm{NO}_{3}\right)$. In low concentrations, they are relatively harmless. Deadly concentration for catfish is 6200 mg $\mathrm{NO}_{3}-\mathrm{N} / 1$ (Hagopian and Riley, 1998).

Uneaten feed, feed particles, fish excrement, algae and remains of microbiological cells are sources for formation of suspended solids (Chen et al. 1997). $1 \mathrm{~kg}$ of fish feed produces $0.43 \mathrm{~kg}$ of suspended solid (SS) particles, additional $9 \%$ of feed volume of suspended solids are produced due to activity of heterotrophic organisms and another $0.09 \%$ - due to activity of nitrifying bacteria. Thus, up to $52 \%$ of total fish feed becomes suspended solids (Summerfelt et al., 2001), during the mineralization of which, oxygen is consumed. In intensive RAS with limited water renewal and inadequate mechanical filtration of recirculating water, suspended solids can accumulate in water, thus producing organic pollution in the system. This problem is especially topical in RAS, because the size of $67 \%$ of suspended solids there varies from 1,5 to $30 \mu \mathrm{m}$, i.e. they are unable to be discarded through the process of sedimentation (Timmons and Ebeling, 2004). In commercial RAS, during mechanical filtration, 70-90\% of suspended solids and 45-55\% of organic material (BDS) are discarded from water (Eels..., 1991). Control of suspended solids is one of the most important RAS management processes as decomposition of sediment can contaminate the water and directly or indirectly affect fish health and the effectiveness of other RAS equipment and processes (Chen et al. 1993). SS can have pathogens and be susceptible to rapid bacteria growth. Also, SS are associated with environmentally induced disease problems and indirectly influence for fish mortality: it can cause fish flipper rot and direct gill damage (Noble and Summerfelt 1996). Suspended and drowning sediment can affect reproduction behaviour, gonad development and limited survival of eggs, embryos and larvae (Pillay and Kutty 2005). Suspended organic outwash in RAS can cause high oxygen consumption, because bacteria decompose suspended outwash further and produce ammonia, phosphate and dissolved organic material solution (Cripps 2000). Small particles and dissolved material are much harder to discard from the system then suspended and non-soluble (Chen et al. 1997). This process of decomposition increases oxygen consumption, thus decreasing water quality in RAS and produced waste.

The balance of chemical processes in the water depends on $\mathrm{pH}$ levels. The most important indexes for fish and biochemical transformations in biofilter, affected by $\mathrm{pH}$ levels are ammonia and carbon dioxide solubility in water. Ammonia solubility, i.e. relative amount of $\mathrm{NH}_{3}$ in water TAN closely depends on $\mathrm{pH}$ index. For example, with water temperature of $25^{\circ} \mathrm{C}$, as $\mathrm{pH}$ decreases from 8.0 to 7.0, the amount of $\mathrm{NH}_{3}$ decreases from 5,38\% to $0,57 \%$. Extreme $\mathrm{pH}$ values for water animals can cause stress and even death. But this will be an indirect influence pf $\mathrm{pH}$, emerging from relation of $\mathrm{pH}$ and other variables, such as carbon dioxide, relation between amounts of $\mathrm{NH}_{3}-\mathrm{N}_{\text {and }} \mathrm{NH}_{4}{ }^{+}-\mathrm{N}$ as well as $\mathrm{NO}_{2}-\mathrm{N}$, which depend on water acidity balance and the increase of which lowers water $\mathrm{pH}$ (Pillay and Kutty 2005). With the temperature of $20^{\circ} \mathrm{C}$ and $\mathrm{pH}$ of 7.0 , there is 0.004 of $\mathrm{NH}_{3}-\mathrm{N}$, but when $\mathrm{pH}$ reaches 10 , the amount of $\mathrm{NH}_{3}-\mathrm{N}_{\text {increases }}$ to 0.8 in the same water temperature (Timmons et al. 2002). According to Aquafarmer (2004), water pH values should fluctuate by less than 0.5 .

Fish, reared in warm conditions (carp, catfish) are more immune to negative changes in physical and chemical water quality parameters than cold water fish (salmon, whitefish). Partially, warm water fish better tolerate much lower oxygen levels and higher fluctuation of water temperature.

Different sources present different water quality requirements for RAS. The most important water quality parameters for aquaculture are presented in table 1.

Table 1. Main water quality parameters and their values in aquaculture farms (based on Goryczko,1999; Ulikowski, 2004, Timmons and Ebeling, 2013)

\begin{tabular}{|c|c|c|}
\hline & Warm water fish & Cold water fish \\
\hline Oxygen concentration ( saturation \%) & $>40$ & $>60$ \\
\hline $\mathrm{pH}$ & $6,5-9,0$ & $6,5-8,5$ \\
\hline Water temperature $\left({ }^{0} \mathrm{C}\right)$ & $<30$ & $<20$ \\
\hline Total ammonia-nitrogen $(\mathrm{mg} / \mathrm{l})$ amount TAN & $<1,0$ & $<0,2$ \\
\hline Nitrites $(\mathrm{mg} / \mathrm{l})$ & $<0,5$ & $<0,2$ \\
\hline Iron level (mg/l) & $<1,0$ & $<0,5$ \\
\hline$(\mathrm{SS})(\mathrm{mg} / \mathrm{l})$ & 100 & 80 \\
\hline Carbon dioxide levels $(\mathrm{mg} / \mathrm{l})$ & 25 & 5 \\
\hline
\end{tabular}


The environmental effect of waste from aquaculture farms, RAS included, manifests through dissolved and suspended organic, food material (nitrogen and phosphorus) and their cloudiness.

The biggest obstacle for economically justified waste management of intensive aquaculture farms using flowing pond or basin systems are high water yields and low pollutant concentrations. The yields of RAS waste are 10-100 times lower, while pollutant concentrations are 10-100 times higher and comparable to that of household waste (Table 2). This allows to organize a more simple and effective waste purification and, with the opportunity, join RAS waste to centralized purification equipment.

Table 2. RAS and household waste parameters (Chen et al.,1997)

\begin{tabular}{|l|c|c|c|c|}
\hline \multirow{2}{*}{\multicolumn{1}{|c|}{ Parameter }} & \multicolumn{2}{c|}{ RAS sludge } & \multicolumn{2}{c|}{ Household waste } \\
\cline { 2 - 5 } & Boundaries & Average value & Boundaries & Average value \\
\hline Concentration of suspended solids (SM)\% & $1,4-2,6$ & 1,8 & $2-8$ & 5 \\
\hline Biologically decomposable portion (\% from SS) & $74,6-86,6$ & 82,2 & $50-80$ & 65 \\
\hline BOD & $1590-3870$ & 2760 & $2000-30000$ & 6000 \\
\hline $\mathrm{NH}_{3}-\mathrm{N}$ & $6,8-25,6$ & 18,3 & $100-800$ & 400 \\
\hline Total phosphorus (TP) & - & 1,3 & - & 0,7 \\
\hline pH & $6,0-7,2$ & 6,7 & $5,0-8,0$ & 6,0 \\
\hline Alkalinity & $284-415$ & 334 & $500-1500$ & 600 \\
\hline
\end{tabular}

There are less suspended solids and the $\mathrm{BOD}_{5}$ index is lower in RAS waste. TAN levels in fresh RAS waste are significantly lower, but they can rapidly increase as anaerobic mineralization processes begin. In the contents of mechanical filter flush, after 4 weeks in sludge thickening containers, due to organic material decomposition reactions, concentrations of dissolved nitrogen and phosphorus increased 7-8 times, while $\mathrm{BOD}_{5}$ index increased almost 20 times (Summerfelt and Vinci, 2003).

The main pollution in aquaculture systems is generated by the metabolic processes of reared organisms. Aquaculture objects are ectothermic (cold-blooded) animals and their activity and feed assimilation changes depending on water temperature. Feed requirements for the organisms of the same species, depending on temperature, can fluctuate from 1 to 4 percent. Thus total pollution, produced in the system, is calculated depending on amount of used feed. It is considered that with correct feeding, $30 \%$ of pollution comes in a form of suspended solids that determine the cloudiness index and BDS. BDS does not have direct influence on fish, but is indirect influence manifests in increased oxygen consumption, decrease in effectiveness of nitrifying biofilters, stimulation of bacteria reproduction and growth (Timmons and Losordo, 1994).

In closed artificial ecosystem with low water volume renewal, nitrogen begins to accumulate. Fish are being fed with protein-rich $(30-60 \%)$ feed. In fish life sustaining processes used up protein nitrogen is expelled through gills -60 $-90 \%$ as ammonia and $9-27 \%$ as urea. For example, salmonid fish only assimilate around $58 \%$ of feed protein, thus around $25 \%$ of nitrogen in feed is expelled through gills and with excrements (Hagopian and Riley, 1998).

The larger part of phosphorus in RAS is in the insoluble fraction, i.e. is not assimilated, thus can be successfully removed during processes of removing cloudiness. The removal of dissolved phosphorus (mainly in the form of phosphates $\left(\mathrm{PO}_{4}\right)$ ) is difficult, thus the main strategy for its elimination is to use feed with lower phosphorus concentrations. The majority of phosphorus compounds are hard to assimilate, thus it is considered that there should be $0,3-0,8 \%$ of phosphorus in the diet of reared organisms. We should keep in mind that phosphorus assimilation in different fish species depends on feed composition. For example, tilapia only assimilates $65 \%$ of phosphorus present in fish flour compared to salmonid fish, while carp practically does not assimilate it at all - the phosphorus it requires is in the ingredients of plant origin (Beveridge, 1984).

The main advantage of RAS is the possibility to get concentrated waste flows which are available for further purification or secondary utilization in economically justified ways. The additional benefit of such systems is the possibility to control waste amounts by organising effective feeding with feed of high quality and effectiveness. Despite higher initial investments, RAS in environmental view is a promising growing system.

The purpose of this research is to evaluate catfish rearing conditions in RAS and the contamination of produced waste.

\section{OBJECT AND RESEARCH METHODS}

African catfish growing process and with it associated factors were researched in JC „Šamas“. This company started growing African catfish (lot. Clarias gariepinus) in 2013.

RAS consists of 28 fish rearing reservoirs, biological filter, stripping filter.

The capacity of growing reservoirs (28 reservoirs, $4 \mathrm{~m}^{3}$ each) - $112 \mathrm{~m}^{3}$, water is changed once every hour. Fish are reared in massive densities - adults up to $500 \mathrm{~kg} / \mathrm{m}^{3}$, smaller $(5$ months of age, weight $-200-250 \mathrm{~g})-\mathrm{up}$ to $150 \mathrm{~kg} / \mathrm{m}^{3}$.

Water temperature is maintained at $23-25^{\circ} \mathrm{C}$. Reared fish are being fed around $160 \mathrm{~kg}$ of feed every day. Around a third of total water volume in the system $-40-45 \mathrm{~m}^{3}$ is renewed each day. $\mathrm{pH}$ level is not regulated artificially, but is being maintained at around 5.85. Such acidic water reduces the effectiveness of biological filter, but at the same time decreases the toxic effect of produced ammonia on the fish.

A stripping filter, which ensures adequate water quality for the reared species and additionally aerates water is used. Four stripping filter sections are installed, with dimensions of 2,75 $\mathrm{m} \times 2,75 \mathrm{~m} \times 3,85 \mathrm{~m}$. 
Water used for fish rearing is drinking water, taken from a borehole. In Table 3, the quality parameters of drinking water from the watering-place are presented.

Table 3. Water quality parameters from watering-place borehole (data from National societal health supervision laboratory Šiauliai division, 2016-05-23)

\begin{tabular}{|c|l|c|c|}
\hline No. & \multicolumn{1}{|c|}{ Water quality parameter } & $\begin{array}{c}\text { Value of water quality } \\
\text { parameter }\end{array}$ & $\begin{array}{c}\text { Allowed up to } \\
(\text { HN 24:2003) }\end{array}$ \\
\hline 1. & Cloudiness & $0,55 \mathrm{DV}$ & $4 \mathrm{DV}$ \\
\hline 2. & $\mathrm{pH}$ & 7,56 & $6,5-9,5$ \\
\hline 3. & Amount of ammonium & $0,97 \mathrm{mg} / \mathrm{l}$ & $0,50 \mathrm{mg} / \mathrm{l}$ \\
\hline 4. & Colour & $22,4 \mathrm{mg} / \mathrm{l} \mathrm{Pt}$ & $30 \mathrm{mg} / \mathrm{Pt}$ \\
\hline 5. & (Total) iron level & $0,17(170) \mathrm{mg} / 1(\mu \mathrm{g} / \mathrm{l})$ & $0,2 \mathrm{mg} / 1 /(200 \mu \mathrm{g} / 1)$ \\
\hline 6. & Specific electricity & $892 \mu \mathrm{S} / \mathrm{cm}$ & $2500 \mu \mathrm{S} / \mathrm{cm}$ \\
\hline 7. & Permanganate index & $4,5 \pm 1,0 \mathrm{mg} / 1 \mathrm{O}_{2}$ & $5,0 \mathrm{mg} / 1 \mathrm{O}_{2}$ \\
\hline
\end{tabular}

JC „ک̌́amas“ RAS scheme is presented in Figure 1.

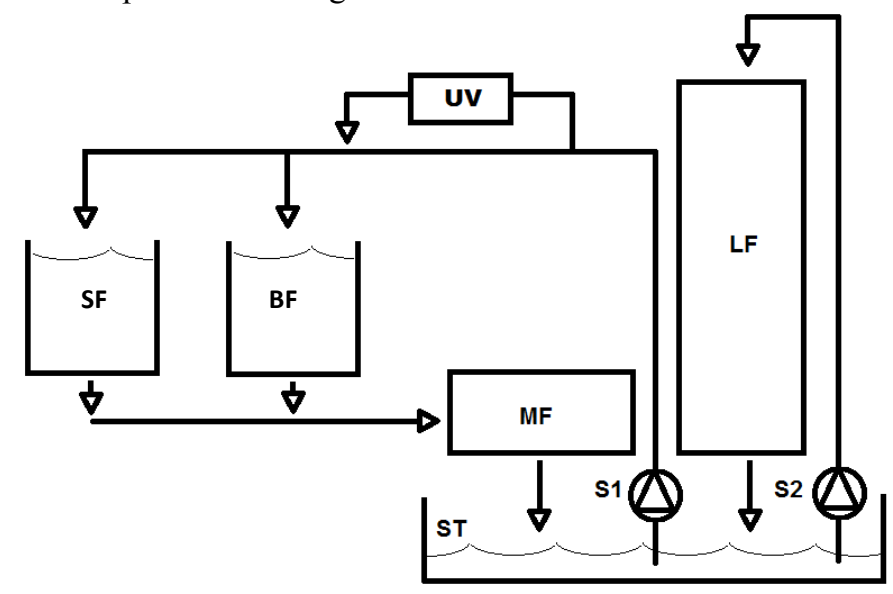

Figure 1. JC „Šamas“ RAS scheme.

$\mathrm{SF}$ and $\mathrm{BF}$ - small and bigger fish growing tanks, MF - mechanical drum filter, ST - pump sump, LF - stripping filter, UV - ultraviolet water disinfection equipment, $\mathrm{S} 1$ and $\mathrm{S} 2$ - pumps.

Water samples were taken from the fish rearing basin that is farthest from biofilter, from the waste drain, in front of biofilter and behind the biofilter.

Water quality parameter (concentration of dissolved oxygen, temperature, $\mathrm{pH}$ and others) analysis was periodically performed using multiparameter measuring instrument HANNA HI9829.

Water quality parameter control analysis was performed in analytical research laboratory of JC „Kauno vandenys“. Quality parameter analysis of waste, produced during the process of fish rearing were performed in LAMMC agrochemical research laboratory and in analytical research laboratory of JC „Kauno vandenys“.

The results of water quality analysis of catfish rearing RAS were summarised by using programme STATISTICA 10, using Basic Statistic tables.

\section{RESULTS OF RESEARCH}

Water quality parameter analysis was performed JC „Šamas“ catfish rearing RAS. The length of the research was 3 months with samples being taken once a week. Research results are presented in Table 4.

Table 4. Water quality values in catfish rearing basins

\begin{tabular}{|c|l|c|c|c|c|c|}
\hline No. & \multicolumn{1}{|c|}{ Index name } & $\mathbf{N}$ & $\begin{array}{c}\text { Average } \\
\text { value }\end{array}$ & Lowest value & Highest value & $\begin{array}{c}\text { Stand. } \\
\text { deviation }\end{array}$ \\
\hline 1. & Temperature, ${ }^{0} \mathrm{C}$ & 12 & 23,30 & 23,11 & 23,80 & 0.12 \\
\hline 2. & Amount of dissolved oxygen, $\mathrm{mg} / \mathrm{l}$ & 12 & 4,53 & 4,44 & 5,2 & 0.26 \\
\hline 3. & $\mathrm{pH}$ & 12 & 6,23 & 5,85 & 6,63 & 0.39 \\
\hline 4. & Nitrites $\left(\mathrm{NO}_{2}{ }^{-}\right), \mathrm{mg} / \mathrm{l}$ & 12 & 0,974 & 0.692 & 1,14 & 0.099 \\
\hline 5. & ${\text { Nitrates }\left(\mathrm{NO}_{3}{ }^{-}\right), \mathrm{mg} / \mathrm{l}}_{12}$ & 478 & 412 & 495 & 0.199 \\
\hline 6. & Ammonium ions, $\mathrm{mg} / \mathrm{l}$ & 12 & 1,171 & 0.621 & 1,341 & 0.56 \\
\hline 7. & $\mathrm{BOD}_{7}, \mathrm{mgO}_{2} / \mathrm{l}$ & 12 & 8,22 & 7,32 & 9,31 & 0,54 \\
\hline 8. & TSS, $\mathrm{mg} / \mathrm{l}$ & 0,1844 & 0,128 & 2,26 & 1,2 \\
\hline
\end{tabular}

The amount of dissolved oxygen $(4,53 \mathrm{mg} / \mathrm{l})$ in the rearing basin is adequate for catfish to feel comfortable and to grow biomass. There is no need for additional oxygen supply. The use of stripping filter ensures the adequate water quality 
for grown species and additionally aerates the water. Due to high growing densities, in the water, returning to the filter from rearing containers, there is practically no dissolved oxygen, while water that is returned to rearing containers, after flowing through the stripping filter and mixing with mechanically filtered water (in this technological system biological filtration is not on continuously, but parallel to water circulation cycle) ensures adequate oxygen level for the grown species: in containers with lower densities, oxygen saturation was up to $61 \%$, in those with higher densities $-43 \%$. According Peteri et al. (2015): ,African catfish can utilize oxygen not only from the ambient water but also from the air with the help of an accessory respiratory organ. The respiratory organ has a cauliflower shape and is located under the gill covers at the upper part of gill arcs. The organ develops when fish are 15-20 days old and 2.5-3.0 cm long. Before reaching this size/age the environmental requirements of catfish are similar to those of other species, for example, cyprinids. Later, as the organ becomes active, the fish are able to tolerate extremely poor water conditions, including zero oxygen content or high ammonia, nitrite and hydrogen sulphide concentrations".

During research, water temperature fluctuated only slightly, with average water temperature of $23.3^{\circ} \mathrm{C}$. The optimal temperature for African catfish is $25-30{ }^{\circ} \mathrm{C}$. In water temperature lower than $20^{\circ} \mathrm{C}$ this species becomes more susceptible to bacterial diseases. In natural conditions these fish can survive even in temperatures of $10^{\circ} \mathrm{C}$. Mortality in RAS is unavoidable at $16^{\circ} \mathrm{C}$ (Hogendoorn et al., 1983, Peteri et al., 2015).

$\mathrm{pH}$ of 7.0 is ideal for growing fish in RAS. Many aquaculture species can tolerate $\mathrm{pH}$ fluctuations from 6.5 to 8.5 . In the samples, taken from catfish rearing system, the $\mathrm{pH}$ varied from 5.58 to 6.63. Such acidic water decreases the effectiveness of biological filter, but also decreases the toxic effect of excreted ammonia on the fish.

As the fish are feeding, around $25 \%$ of food becomes waste. Such waste need to be removed from the system as fast as possible, without causing turbulence (Timmons and Ebeling, 2013). Some authors (Timmons et al. 2002 and Pillay and Kutty, 2005) found that in aquaculture, concentration of SS should be lower than $80 \mathrm{mg} / 1$, for salmonid fish according to Aquafarmer (2005) - around $4.5 \mathrm{mg} / \mathrm{l}$ as safe, needs to be corrected when $15 \mathrm{mg} / \mathrm{l}$ concentration is reached. There is not a significant amount of suspended solids in the taken samples, thus they are being removed from the system effectively.

Ammonia nitrogen is excreted by the fish into the water as a result of protein metabolism. The average amount of ammonia nitrogen in analysed catfish rearing RAS water was on average $1,171 \mathrm{mg} / \mathrm{l}$. The recommended amount of ammonia nitrogen for catfish is lower than $2.5 \mathrm{mg} / \mathrm{l}$. Larger amounts of non-iodized ammonia are found in water with higher $\mathrm{pH}$ levels and warmer temperatures. Usually, concentrations of $\mathrm{NH}_{3}-\mathrm{N}$ need to be maintained as lower than 0.05 $\mathrm{mg} / \mathrm{l}$ and TAN concentration lower than $1.0 \mathrm{mg} / \mathrm{l}$ (Timmons et al. 2002).

In the issue (Water, 2014) it is stated that catfish are more immune to the effect of nitrites than trout, but nitrite concentration of $29 \mathrm{mg} / \mathrm{l}$ can kill them. In analysed water samples nitrite levels are on average 0,974 mg/l. The recommended amount of nitrites for catfish is lower than $0.5 \mathrm{mg} / \mathrm{l}$.

In analysed water samples we noticed relatively high nitrate values - from 412 to $495 \mathrm{mg} / \mathrm{l}$. Catfish can tolerate higher amounts of nitrates. In order to lower the concentration of accumulated nitrates, no less than $10 \%$ of total water volume in the system needs to be changed every day. Nitrates are final product of nitrogen division and in order for nitrates to not become nitrites or ammonium during chemical processes in water, a high concentration of dissolved oxygen needs to be maintained. Large volumes of nitrates (around $100 \mathrm{mg} / \mathrm{L}$ ) can have a negative impact on growth and feed recycling. Camargo et al. (2005) cite research, which has shown that channel catfish (Ictalurus punctatus), after being in the water with $\mathrm{NO}_{3}-\mathrm{N}$ concentration of $90 \mathrm{mg} / \mathrm{l}$ for 164 days were healthy and negative effect was only seen when $\mathrm{NO}_{3}-$ $N$ concentration reached $1355 \mathrm{mg} / 1$ after 96 hours in $22^{\circ} \mathrm{C}$ temperature water. Deadly concentration for catfish is 6200 mg $\mathrm{NO}_{3}-\mathrm{N} / 1$ (Hagopian and Riley, 1998). Usually, in order to maintain an adequate concentration of nitrates in RAS, it is enough to regularly change a small portion of system's water with fresh water.

The biochemical oxygen consumption index corresponds to RAS water quality requirements.

In a day, $40 \mathrm{~kg}$ of sludge are produced in this farm, while $1200 \mathrm{~kg}$ are produced in a month.

After analysing RAS waste, i.e. the water of mechanical filter flush flow, the following results were obtained. They quite well correlate with values presented in literature. The data is presented in Table 5.

Table 5. contamination of waste, produced in catfish rearing farm JC „ک̌amas“

\begin{tabular}{|c|l|c|c|c|c|c|}
\hline No. & \multicolumn{1}{|c|}{ Index Name } & N & $\begin{array}{c}\text { Average } \\
\text { value }\end{array}$ & $\begin{array}{c}\text { lowest } \\
\text { value }\end{array}$ & $\begin{array}{c}\text { Highest } \\
\text { value }\end{array}$ & Stand. deviation \\
\hline 1. & Suspended solids, $\mathrm{mg} / \mathrm{l}$ & 12 & 1156 & 1136 & 1176 & 12,56 \\
\hline 2. & Biological oxygen demand $\mathrm{BOD}_{7}, \mathrm{mgO}_{2} / \mathrm{l} ;$ & 12 & 570 & 534 & 597 & 15,36 \\
\hline 3. & Chemical oxygen demand $\mathrm{COD}, \mathrm{mgO}_{2} / \mathrm{l} ;$ & 12 & 1170 & 1136 & 1323 & 16.27 \\
\hline 4. & Ammonia nitrogen, $\mathrm{mg} / \mathrm{l}$ & 12 & 39.16 & 31 & 47 & 3.63 \\
\hline 5. & Total nitrogen, $\mathrm{mg} / \mathrm{l}$ & 12 & 58.08 & 52 & 63 & 3.34 \\
\hline 6. & Total phosphorus, $\mathrm{mg} / \mathrm{l}$ & 12 & 26.67 & 23 & 30 & 2.14 \\
\hline
\end{tabular}

The contamination in aquaculture systems can be managed by manipulating feed composition. It is important to use feed with balanced amino acids in them in order for protein in the feed to be maximally assimilated, i.e. would be used to grow body mass. A portion of protein can be replaced with fat and carbohydrates, thus increasing the energy value of the feed and at the same time reducing the amount of consumption, i.e. improving feeding coefficient.

One of topical problems for system breeders is to return a maximum amount of purified waste into the system in order to save energy, used for providing and heating additional water to the system and to save in paying for waste purification services (RAS waste are purified in centralized town waste management plants). 


\section{CONCLUSIONS}

1. In catfish rearing basins determined $\mathrm{pH}$ values fluctuated from 5,58 to 6,63 . Such acidic water reduces the effectiveness of biological filter, but at the same time decreases the toxic effect of produced ammonia on the fish.

2. In analysed samples, relatively high nitrate values were determined - from 412 to $495 \mathrm{mg} / \mathrm{l}$. In order to decrease the concentration of accumulated nitrates, no less than $10 \%$ of total water in the system needs to be replaced with fresh water.

3. The main sources of contamination in RAS are unconsumed food and fish metabolism waste, thus contamination in aquaculture systems can be managed by manipulating feed composition.

\section{REFERENCES}

1. Aquafarmer. 2004. The farming of Arctic charr. Technical Institute of Iceland, the Holar University College and the Aquaculture Development Centre of Ireland. November 2007 - January 2008.

2. Camargo, J. A., Alonso, A., Salamanca, A. 2005. Nitrate toxicity to aquatic animals: a review with new data for freshwater invertebrates. Chemosphere, Vol. 58, pp. 1255-1267.https://doi.org/10.1016/j.chemosphere.2004.10.044

3. Chen, S.; Coffin, D. E.; Malone, R. F. 1997. Sludge production and management for recirculating aquaculture systems. Journal of World Aquaculture Society, Vol. 28, pp. 303-315. https://doi.org/10.1111/j.1749-7345.1997.tb00278.x

4. Badiola M., Mendiola D., Bostock J. 2012. Recirculating Aquaculture Systems (RAS) analysis: Main issues on management and future challenges. Aquacultural Engineering, No. 51, pp. 26-35. https://doi.org/10.1016/j.aquaeng.2012.07.004

5. Bergheim, A. 2000: Solids management and removal for intensive land-based aquaculture production systems. Aquacultural Engineering, Vol. 22, pp. 33-56. https://doi.org/10.1016/S0144-8609(00)00031-5

6. Beveridge, M. C. M. 1984. Cage and Pen Fish Farming. Carrying Capacity Models and Environmental Impact. FAO Fish. Tech. Pap. [online]. Available at: http://www.fao.org/docrep/005/ad021e/ad021e00.htm\#TOC

7. Eel farming in re-circulation systems. 2001. Aquaculture Technical Manual. Bord Iascaigh Mhara - Irish Sea Fisheries Board.

8. Forsberg, O.I. 1997. The impact of varying feeding regimes on oxygen consumption and excretion of carbon dioxide and nitrogen in post-smolt Atlantic salmon Salmo salar L. Aquaculture Research, Vol. 28, pp. 29-41. https://doi.org/10.1111/j.13652109.1997.tb01312.x

9. Hogendoorn H, Jansen Jaj, Koops WJ, Michaels Mam, Van Ewijk PH and Van Hees JP. (1983) Growth and production of the African cat-fish, Clarias lazera $(\mathrm{C} \& \mathrm{~V})$. II: Effects of body weight, temperature and feeding level in intensive tank culture. Aquaculture, Vol. 34, pp. 265-285. https://doi.org/10.1016/0044-8486(83)90208-9

Hagopian, D. S.; Riley, J. G. 1998. A closer look at the bacteriology of nitrification. Aquacultural Engineering, Vol. 18, Iss. 4, pp. 223-244. https://doi.org/10.1016/S0144-8609(98)00032-6

10. Goryczko, K. 1999. Pstrągi. Chow i hodowla. Poradnik hodowcy. Wydawnictwo IRS, Olsztyn.

11. Noble, A.C. and Summerfelt, S.T. 1996. Disease encountered in rainbow trout cultured in recirculating systems. Annual Review of Fish Diseases, Vol. 6, pp. 65-92. https://doi.org/10.1016/S0959-8030(96)90006-X

12. Meinelt, T., Kroupova, H., Stüber, A., Rennert, B., Wienke, A., Steinberg, C.E.W., 2010. Can dissolved aquatic humic substances reduce the toxicity of ammonia and nitrite in recirculating aquaculture systems? Aquaculture Vol. 306, pp. 378383.https://doi.org/10.1016/j.aquaculture.2010.06.007

13. Parker, E. V. 2000. Oxygen management at commercial freshwater recirculating aquaculture system: M. S. Thesis. University of New Brunswick. 144 p.

14. Peteri A., Moth-Poulsen T., Kovacs E., Toth I., Woynarovich A. 2015. African catfish (Clarias gariepinus, Burchell 1822) production with special reference to temperate zones. FAO. A Manual. Rome, Italy.

15. Pillay, T.V.R. and Kutty, M.N. 2005. Aquaculture, Principles and Practices, 2nd Edition. Blackwell Publishing Ltd, Oxford, UK. $630 \mathrm{p}$.

16. Summerfield, S. T.; Vinci, B. J. 2008. Better Management Practices for Recirculating Aquaculture Systems. In: Environmental Best Management Practices for Aquaculture. Tucker, S., C., Hargreaves J., A. (ed). P. 592. Wiley Blackwell publishing. https://doi.org/10.1002/9780813818672.ch10

17. Summerfelt, R.C., Penne, C.R., 2005. Solids removal in a recirculating aquaculture system where the majority of flow bypasses the microscreen filter. Aquacultural Engineering, Vol. 33, pp. 214-224. https://doi.org/10.1016/j.aquaeng.2005.02.003

18. Summerfelt, S. T.; Binkowski, F. B.; Malison, J. A.; Reinemann, D. J. 2001. Aquacultural wastes and effluents: their characteristics, removal and beneficial uses, Plan of work for grant \#2001-38500-10369, 2001. https://www.ncrac.org/files/project/files/wastesprojectoutline3.pdf

19. Timmons, M.B and Losordo, T.M. 1994. Aquaculture Water Reuse Systems: Engineering Design and management. 1 st Edition, Amsterdam: Elsevier. ISBN 0-444-89585-X.

20. Timmons. B. ,Ebeling J. M. 2013. Recirculating Aquaculture, 3rd Edition. Ithaca Publishing Company, LLC; November 14, 2013. $788 \mathrm{p}$.

21. Timmons, M. B.; Ebeling, J. M. 2007. Recirculating Aquaculture. Cayuga Aqua Ventures, Ithaca, NY.

22. Timmons, M.B, Holder, J.L and Ebeling, J. M. 2004. Application of Microbead Biological Filters. Biological \& Environmental Engineering, Cornell University, Ithaca N.Y.

23. Timmons, M. B. H., J.L. Ebeling, J.M. Application of Microbead Filters. 2004. In: Design and Selection of Biological Filters for Freshwater and Marine Applications, November 8-11, 2004, Honolulu, Hawaii, Oceanic Institute, Waimanalo, HI. 
24. Timmons, M.B, Ebeling, J.M, Wheaton, F.W, Summerfelt, S.T and Vinci, B.J. 2002. Recirculating Aquaculture Systems. 2nd Northeastern Regional Aquaculture Center Publication No. 01-002.

25. Ulikowski, D. 2004. Kaszubskie sumy. Komunikaty rybackie, 1, 3-6.

26. Water Quality Management for Recirculating Aquaculture. http://www.agmrc.org/media/cms/FA3A_561BD17CD3C4D.pdf.

27. Van de Nieuwegiessen PG, Olwo J, Khong S, Verreth JAJ, Schrama JW (2009). Effects of age and stocking density on the welfare of African catfish, ClariasgariepinusBurchell. Aquaculture, Vol. 288, pp. 69-75. https://doi.org/10.1016/j.aquaculture.2008.11.009 